Meta

Journal des traducteurs

Translators' Journal

\title{
Vagaries of News Translation on Canadian Broadcasting Corporation Television: Traces of History
}

\section{Kyle Conway}

Volume 59, numéro 3, décembre 2014

Traduction et plurilinguisme officiel

Translation and Official Multilingualism

URI : https://id.erudit.org/iderudit/1028660ar

DOI : https://doi.org/10.7202/1028660ar

Aller au sommaire du numéro

Éditeur(s)

Les Presses de l’Université de Montréal

ISSN

0026-0452 (imprimé)

1492-1421 (numérique)

Découvrir la revue

Citer cet article

Conway, K. (2014). Vagaries of News Translation on Canadian Broadcasting Corporation Television: Traces of History. Meta, 59(3), 620-635.

https://doi.org/10.7202/1028660ar
Résumé de l'article

Le présent article décrit une série de tentatives - toutes échouées - par les réseaux anglais et français de la Société Radio-Canada de produire des émissions de nouvelles traduites. Sur un premier plan, il examine les raisons pour lesquelles la traduction journalistique paraît à des moments de crise comme un outil pour résoudre certaines questions identitaires au Canada, ainsi que les raisons pour lesquelles l'idée de produire des émissions de nouvelles traduites n'est pas réalisée. Sur un deuxième plan, il considère un dilemme méthodologique et épistémologique auquel les historiens doivent faire face : que faire quand les documents qu'ils cherchent ne sont pas conservés parce que les journalistes conçoivent la traduction d'une manière différente ? Cet article recommande que les historiens se tournent vers des " para-archives ", ou des collections créées et conservées par des organismes non-journalistiques, qui contiennent des descriptions des documents qui n'existent plus. Ces para-archives peuvent fournir de quoi créer des récits plausibles au sujet des intérêts contradictoires qui militent contre la production d'émissions de nouvelles traduites. Elles peuvent aussi rendre plus claire la manière dont les historiens produisent les catégories qu'ils emploient pour définir leur objet d'étude.
Ce document est protégé par la loi sur le droit d'auteur. L'utilisation des services d'Érudit (y compris la reproduction) est assujettie à sa politique d'utilisation que vous pouvez consulter en ligne.

https://apropos.erudit.org/fr/usagers/politique-dutilisation/ 


\title{
Vagaries of News Translation on \\ Canadian Broadcasting Corporation Television: Traces of History
}

\author{
KYLE CONWAY \\ University of North Dakota, Grand Forks, United States of America \\ conway.kyle@gmail.com
}

\section{RÉSUMÉ}

Le présent article décrit une série de tentatives - toutes échouées - par les réseaux anglais et français de la Société Radio-Canada de produire des émissions de nouvelles traduites. Sur un premier plan, il examine les raisons pour lesquelles la traduction journalistique paraît à des moments de crise comme un outil pour résoudre certaines questions identitaires au Canada, ainsi que les raisons pour lesquelles l'idée de produire des émissions de nouvelles traduites n'est pas réalisée. Sur un deuxième plan, il considère un dilemme méthodologique et épistémologique auquel les historiens doivent faire face: que faire quand les documents qu'ils cherchent ne sont pas conservés parce que les journalistes conçoivent la traduction d'une manière différente? Cet article recommande que les historiens se tournent vers des «para-archives», ou des collections créées et conservées par des organismes non-journalistiques, qui contiennent des descriptions des documents qui n'existent plus. Ces para-archives peuvent fournir de quoi créer des récits plausibles au sujet des intérêts contradictoires qui militent contre la production d'émissions de nouvelles traduites. Elles peuvent aussi rendre plus claire la manière dont les historiens produisent les catégories qu'ils emploient pour définir leur objet d'étude.

\begin{abstract}
This article describes a series of failed attempts by the English and French networks of the Canadian Broadcasting Corporation to present translated news. On one level, it is concerned with the impulse that prompts people during moments of crisis to suggest translated news as a solution to a problems related to Canadian identity and the reasons their suggestions to translate news programs are not acted upon. On a deeper level, it is concerned with a methodological and epistemological problem facing translation historians: what happens when the relevant documents are not preserved because journalists' notions of translation differ from those of historians? It recommends that historians turn to "para-archives," or collections created and preserved by non-news organizations, that contain descriptions of the documents journalists have not kept. These para-archives can provide evidence for the creation of plausible narratives about the competing interests shaping decisions not to produce translated news. They can also reveal how historians actively produce the categories they use to define their object of study.
\end{abstract}

\section{MOTS-CLÉS/KEYWORDS}

traduction journalistique; Société Radio-Canada; Canadian Broadcasting Corporation; historiographie; archives; Newsworld; Réseau de l'information

news translation; Canadian Broadcasting Corporation; Société Radio-Canada; historiography; archives; Newsworld; Réseau de l'information 


\section{Introduction: history and news translation}

In this article, I describe a series of attempts to bring translated news in various forms to Canadian Broadcasting Corporation television. ${ }^{1}$ They span five decades, from the early 1960s to 2012, and they all failed. On one level, I am presenting a case study concerned with two things: the impulse that prompts people to suggest translated news as a solution to a problem and the reasons their suggestions are not acted upon. In this way, I help fill an empirical gap in translation history, where the news has been largely neglected (O'Sullivan 2012). ${ }^{2}$

At a deeper level, I am also concerned with the implications of this case study for the field of translation history. It presents a specific set of challenges: it is not a history of translation but of an institution where translation sometimes takes place. Moreover, the Canadian Broadcasting Corporation is largely indifferent to translation as such: its news organizations, as well as individual journalists themselves, tend to treat linguistic re-expression as one tool among others that allow them to report stories in professionally responsible ways. Finally, it is a history about unrealized potential where no one at the Corporation preserved records of its attempts to develop new programs or incorporate translation into its existing programs, at least not in a searchable archive. This leaves historians in a difficult situation and draws attention to the fact that we do not merely find objects of study; instead, by asking questions with specific ends in mind, we actively produce the categories we use to identify the objects we want to describe. Thus this case study raises questions about archives and the relations of power that influence their construction.

I divide this article into three parts. First is a description of the reflexivity that has come to characterize approaches to translation history, with an emphasis on how scholars produce their objects of study through the questions they ask. Second is a list of proposals punctuating the history of Canadian television and the contexts in which they were made. It is likely an incomplete list because it relies on off-hand comments that were documented largely by accident. Third is an account of the single case of a well documented proposal. It describes efforts between 1989 and 1994 to provide subtitled versions of Le Téléjournal from the Corporation's Frenchlanguage network and various programs from its English-language network on its all-news cable networks Newsworld and the Réseau de l'information. Canada was working through an existential, constitutional crisis, where Quebec wanted a recognition of its special place in Canada that the rest of Canada was not willing to grant. The nature of the crisis was also the proposal's undoing: to many journalists in Quebec, the proposal seemed to represent a danger that English-Canadian journalists would have too much influence in programs aired on their province.

In effect, this article is about paths not followed. It is not about how or even why a specific form of translation is performed, but instead the very conditions that make such translation possible or, ultimately, impossible.

\section{Silence in the archive: What is the object of study?}

In the last two decades, the field of translation studies has grappled with what Carol O'Sullivan calls "methodological self-questionings about how we do or should carry out historical work in translation [...]" (2012: 132). No longer does the historical object appear as given, as terms such as "source" and "target text" seem to imply. 
Instead, scholars have begun to ask how the categories they use to define their objects of study are themselves shaped by historical circumstances.

Recent work in translation history has been marked by two theoretical moves relevant to my purposes here. The first is a shift in emphasis from translations to translators. In Method in Translation History, for instance, Anthony Pym argues that the "central object should be the human translator" and that historians should ask why a certain time and place produce translators, what contexts they work within, and how translation historiography - the work performed by historians - "address[es] problems affecting [historians'] own situation" (1998: ix-x). He is concerned, in the final analysis, with the forces that limit the range of options available to translators and influence the choices they make.

The second move, which works in tandem with the first, is an expansion of ideas of what constitutes translation. Lieven D'hulst (2010), for instance, posits eight questions historians should ask: who is a translator? What is translated? Where is it published, and by whom? Who aids translators? What motivates translators to create translations? How are translations made? When are they made? And finally, what are their effects? Such questions do not presuppose their object. In fact, they force historians to examine the methodological tools at their disposal. The categories they use to define their objects of study are not universal, despite their appearances. On the contrary, they too are products of historical circumstances (see Werner and Zimmerman 2003). This reflexive move allows D'hulst to ask about forms of transfer (or movement and transformation of texts) that might not be readily recognized as translation in a strict sense. In his study of the evolution of print culture in nineteenth century Belgium, for instance, he observes

partial quotation of critical texts originally published in French journals; full reproduction of articles (often without mentioning the source); parody, pastiche and imitation of French poems; edited versions of Belgian medieval texts; and translation from Flemish and German. (2012: 146)

The question of object is especially pertinent in the case of news translation. We must ask two distinct but related questions: what is news translation, and what do scholars of news translation take as their object of study? Esperança Bielsa and Susan Bassnett (2009) begin to answer the first question in their examination of news agencies such as Agence France Presse and Reuters, which have developed efficient ways to write and distribute stories to a range of audiences divided along geographic, cultural, and linguistic lines. Journalists frequently adapt stories from one language to another, a process that goes beyond translation in a strict sense to include the revision of headlines or leads, the elimination or addition of information to suit audiences' cultural competencies, or the reordering of paragraphs (Bielsa and Bassnett 2009: 64). In fact,

[w] hen journalists talk about 'translation,' they tend to be thinking of what others might term 'literal translation,' and [...] some of the views expressed by people who prefer to call themselves 'international journalists' rather than translators reveal that the way in which they conceive of translation is very different from the way in which linguists or language teachers might. Information that passes between cultures through news agencies is not only 'translated' in the interlingual sense, it is reshaped, edited, synthesized and transformed for the consumption of a new set of readers. (Bielsa and Bassnett 2009: 1-2) 
But the rewriting of stories does not exhaust "news translation" as a category; linguistic re-expression takes place at many more points in the production of a news story. It can take place during the process of news gathering, where reporters enlist the help of "fixers" who introduce them to sources and act as linguistic and cultural interpreters (Goldscheider 2004). It can also occur during the writing stage, where reporters compile their sources into a coherent story. It often concludes with "transediting," to use Karen Stetting's frequently cited term, where editors "improve clarity, relevance, and adherence to the conventions of the textual type in question" (Stetting 1989: 372; see also van Doorslaer 2010b). As a result, many of the usual terms of translation studies (such as "source" and "target text") do not necessarily apply. Luc van Doorslaer (2010a) describes this state of affairs as the result of the "double extension of translation in the journalistic field." Borrowing from Roman Jakobson, he argues that news translation involves intralinguistic and intersemiotic (in addition to interlinguistic) translation, but beyond that, it also involves "the combination of a (barely reconstructable) multi-source situation with a highly pragmatic use of translation in potentially all three fields as described by Jakobson" (2010a: 181). What is extended first is the idea of translation, beyond its common-sense notion of interlinguistic transfer; what is extended second is the idea of the object of Translation Studies, beyond notions of source and target texts. The result is a wide range of possibilities of the modes and degrees of translation, as well as the actors who perform it, as Table 1 illustrates: ${ }^{3}$

TABLE 1

Piecemeal and full translation in print/internet and television news

\begin{tabular}{|c|c|c|c|c|c|c|c|}
\hline \multirow{4}{*}{$\begin{array}{l}\text { Piecemeal } \\
\text { translation }\end{array}$} & & \multicolumn{2}{|c|}{ Print/internet } & \multicolumn{4}{|c|}{ Television } \\
\hline & \multirow{2}{*}{$\begin{array}{l}\text { What is } \\
\text { translated? }\end{array}$} & \multirow{2}{*}{$\begin{array}{l}\text { quotations in } \\
\text { language } \\
\text { reporter } \\
\text { does not } \\
\text { speak }\end{array}$} & \multirow{2}{*}{\begin{tabular}{|l|} 
quotations, \\
document \\
excerpts, \\
other news \\
stories in \\
language \\
reporter \\
speaks \\
quotations, \\
documents, \\
etc., \\
incorporated \\
into new \\
story \\
\end{tabular}} & \multicolumn{2}{|c|}{$\begin{array}{l}\text { speech in language } \\
\text { reporter does not speak }\end{array}$} & \multicolumn{2}{|c|}{$\begin{array}{l}\text { speech, document } \\
\text { excerpts, other news } \\
\text { stories in language } \\
\text { reporter speaks }\end{array}$} \\
\hline & & & & \begin{tabular}{|l|} 
paraphrases \\
or voice- \\
overs
\end{tabular} & subtitles & $\begin{array}{l}\text { paraphrases } \\
\text { or } \\
\text { voice-overs }\end{array}$ & subtitles \\
\hline & $\begin{array}{l}\text { Who } \\
\text { performs } \\
\text { translation? }\end{array}$ & $\begin{array}{l}\text { reporter in } \\
\text { consultation } \\
\text { with "fixer" } \\
\text { who speaks } \\
\text { local } \\
\text { language }\end{array}$ & reporter & \begin{tabular}{|l|} 
reporter in \\
consultation \\
with "fixer" \\
who speaks \\
local \\
language \\
\end{tabular} & $\begin{array}{l}\text { reporter, } \\
\text { "fixer," } \\
\text { and tech- } \\
\text { nician } \\
\text { who adds } \\
\text { subtitles } \\
\end{array}$ & $\begin{array}{l}\text { reporter/ } \\
\text { anchor }\end{array}$ & $\begin{array}{l}\text { reporter/ } \\
\text { anchor } \\
\text { and } \\
\text { technician } \\
\text { who adds } \\
\text { subtitles }\end{array}$ \\
\hline \multirow[t]{3}{*}{$\begin{array}{l}\text { Full } \\
\text { translation }\end{array}$} & $\begin{array}{l}\text { What is } \\
\text { translated? }\end{array}$ & \multicolumn{2}{|l|}{ entire articles } & \multicolumn{4}{|c|}{ entire stories or episodes } \\
\hline & $\begin{array}{l}\text { What form } \\
\text { does } \\
\text { translation } \\
\text { take? }\end{array}$ & \multicolumn{2}{|l|}{ rewritten text } & \multicolumn{4}{|c|}{ subtitled stories or episodes } \\
\hline & $\begin{array}{l}\text { Who } \\
\text { performs } \\
\text { translation? }\end{array}$ & \multicolumn{2}{|l|}{ Reporter } & \multicolumn{4}{|c|}{ reporter and technician who adds subtitles } \\
\hline
\end{tabular}


In other words, in answer to the second question, news translation does not present a ready-made object of study. Instead, its objects result from the interplay between the raw material to which scholars have access (not just individual stories but also websites, newspapers, programs, and so on, that contain some form of translated language) and the questions they ask. Different types of raw material provide answers for different types of questions, and scholars must find raw material that yields relevant data to analyze. For instance, much of the early work on news translation was concerned with journalists' roles as cultural intermediaries. Scholars asked questions such as, how do journalists act as gatekeepers when they choose articles to translate (Fujii 1988)? What pressures affect bilingual reporters when they act as interpreters in live television news (Tsai 2005)? In these cases, the object of study was reporters themselves in the context of the workplace. For other examples, consider Table 2, which describes objects ranging from a single broadcast story to a broad corpus of print-based stories:

TABLE 2

\section{Research questions and their respective objects of study}

\begin{tabular}{|l|l|}
\hline Research questions & Objects of study \\
\hline $\begin{array}{l}\text { How does subtitling register the subtle ways in } \\
\text { which journalists are socially, historically, and } \\
\text { culturally situated? }\end{array}$ & $\begin{array}{l}\text { single controversial episode of a television } \\
\text { news-magazine (Kang 2012) }\end{array}$ \\
\hline $\begin{array}{l}\text { How does one story in one language become } \\
\text { multiple restructured stories in other languages? }\end{array}$ & $\begin{array}{l}\text { corpus of all stories from a news agency's website } \\
\text { over the course of one day (Bielsa and Bassnett } \\
\text { 2009: 94-116) }\end{array}$ \\
\hline $\begin{array}{l}\text { How do journalists employ ideologically charged } \\
\text { words? }\end{array}$ & $\begin{array}{l}\text { corpus of stories from a range of internet sources } \\
\text { about a specific historical event (Valdeón 2009) }\end{array}$ \\
\hline $\begin{array}{l}\text { How do viewers come to know people unlike } \\
\text { themselves through television news? }\end{array}$ & $\begin{array}{l}\text { corpus of televised stories about cultural "others" } \\
\text { during a specific historical event that include } \\
\text { snippets of translated speech (Conway 2011: } \\
\text { 104-157) }\end{array}$ \\
\hline $\begin{array}{l}\text { What does news translation reveal about the } \\
\text { influence of English syntax on French? }\end{array}$ & $\begin{array}{l}\text { broad corpus of news agency dispatches about a } \\
\text { range of topics translated in their entirety } \\
\text { (McLaughlin 2011) }\end{array}$ \\
\hline
\end{tabular}

The approach I adopt here follows these trends in its emphasis on historically situated translators and its broad conception of the act of translation, but I ask a different type of question. First, I examine failed efforts to provide translations, broadly conceived. With one notable exception, detailed below, there are no texts to examine because they were never produced. Second, my concern rests more squarely on the nature of the evidence that makes historical claims possible. For that, I borrow from historian Michel-Rolph Trouillot, whose interest lies in the forces that shape how historians find and organize traces of evidence to construct historical narratives. Trouillot is especially interested in what is left out or, as he puts it, where "silences" enter the process of historical production. To that end, he identifies four crucial moments where silences are introduced:

the moment of fact creation (the making of sources); the moment of fact assembly (the making of archives); the moment of fact retrieval (the making of narrative); and the moment of retrospective significance (the making of history in the final instance). (1995: 26) 
In the case of the Canadian Broadcasting Corporation and translation, the most important silenced moment is that of fact assembly. While researching my book on translation in CBC and Radio-Canada news in the 1990s (Conway 2011), I discovered two things. First, although the $\mathrm{CBC}$ and Radio-Canada both have extensive video archives of their news programs, their archive of internal written documents is ad hoc, made up of items different people at different times thought were important, but without a clear guiding principle or any claim to exhaustiveness. In-house reports and production notes, when they still exist, are carefully guarded out of a concern that they might contain information (such as audience research) not intended for public consumption. Second, the archive, such as it is, is not indexed, and it is dispersed across Canada, although most documents about the national network are in Toronto, Montreal, or Ottawa. Finding items is a matter of luck or - what amounts to the same thing - of finding a reference librarian who knows the people who saved the document a researcher wants. But even then, gaps are common.

That such an archive had the potential to exist is clear from what we might call "para-archival" documents such as government reports that refer to internal Corporation documents. In other words, at one point, the sources existed, frequently in the form of memoranda or proposals from Corporation management about innovations that might be had through translation, as the next section describes. Why did such documents not end up in an archive? One plausible explanation is that they simply did not seem important. Journalists at the Canadian Broadcasting Corporation, like those described by Bielsa and Bassnett (2009), tend to think of the category of translation in restricted terms. As a result, questions of translation are largely invisible in the Corporation's news departments. Discussions of translation are absent, for instance, from the CBC's training manuals (Knight 2003; St. James 2002), its journalistic policy manual (CBC 1988), and its television style guide (Everton 1999). Why establish policies for something journalists usually don't do (the wholesale rewriting of stories) or something they do as a matter of course (gather information from a variety of sources)? Instead, these manuals talk about how to tell compelling stories, how to make language more lively, or at an institutional level, how to deal with potential conflicts of interest.

The silence in the archive has a direct impact on the narratives historians tell about the Canadian Broadcasting Corporation (for instance, with respect to its role in Canadian nation-building). Translation is absent, and its absence is made all the more conspicuous by the various mandates given to the Corporation to represent Canada to Canadians of both major linguistic groups. ${ }^{4}$ Trouillot compensates for such silences, among other ways, by making them "speak for themselves": he identifies competing interests at each moment in the process of narrative creation and names the ways one set of interests wins out over another (1995: 27-30). In this way, he brings questions of power to the forefront and asks what stories we can tell if we pay attention to perspectives that have been obscured or suppressed.

This is the approach I adopt in the following sections. I look outside the Corporation's limited archive to find specific instances where news translation appeared to offer a solution to problems Canada faced. To identify competing interests, I ask, what was the nature of the problems? Who felt they had a stake in the solutions? And how did one set of interests win out over the others? 


\section{Translation in Canadian news: a series of near misses}

At its most basic, the logic underpinning most proposals for translated news looked like this: if translation made it possible for Canada's diverse communities to share the same news, they would also come to share the same reference points, and, as a result, they might finally see eye-to-eye. So why not provide translated news?

Policy analyst David Eaves provides the most recent example in a 2012 article he wrote as part of a series called The Network: The CBC \& Public Broadcasting: A National Conversation, published by the Toronto Star. The series came in response to the draconian budget cuts implemented by Stephen Harper's Conservative government, which affected the Canadian Broadcasting Corporation and many other organizations funded by Parliament. He wrote:

While a diverse media industry is a good thing, not one Canadian media outlet, be it in print, radio or television, endeavours to create a common set of priorities that can simultaneously engage all Canadians. Some may argue that such a task is impossible. Possibly. But if we are always working from different questions, premises, analysis and data sets, how can we reasonably expect to have a shared debate on public policy and politics? With no media identifying, prioritizing and analyzing the country's collective challenges on behalf of the whole public, is it possible to have dialogue, engagement or even democracy?

Why not air a single broadcast simultaneously in English and in French? When the discussion is in French, subtitle or dub it in English. When it's in English, subtitle or dub it in French. Let's hear what French experts at [the Université du Québec à Montréal] are thinking. Let's interview northerners in Inuktitut and subtitle or dub that as well. Moreover, why don't we unify the editorial boards and compel them to develop a single Canadian news agenda - one that respects and engages regional differences? ${ }^{5}$

What Eaves appeared not to realize, however, was that his idea was not new. In fact, many people had proposed it before, from citizens testifying before the Royal Commission on Bilingualism and Biculturalism in the 1960s to the president of Canada's broadcast regulator, the Canadian Radio-television and Telecommunications Commission (CRTC), in the 1990s. In each case, such proposals came at moments of crisis. In 2012, the crisis was existential: how could the Corporation justify its continued existence when viewers had so many other choices?

In decades before that, the crisis related to Quebec. Each time the threat of Quebec separatism loomed on the horizon, someone would point out that Anglophones and Francophones were seeing very different news, a factor that perpetuated - and was perpetuated by - their mutual solitudes. In fact, the first mentions of translated news I have found come from the 1960s and coincide with the rise of the modern Quebec nationalist movement. For instance, Lester Pearson's government responded to the threat of Quebec separatism by creating the Royal Commission on Bilingualism and Biculturalism (the B\&B Commission) and giving it the mandate to "recommend what steps should be taken to develop the Canadian Confederation on the basis of an equal partnership" between the French and the English (Canada 1965: 151). In its preliminary report, it noted that "few programs are carried on both the English and French networks of the Canadian Broadcasting Corporation, and [...] news, information and opinion programs vary greatly between the two" (Canada 1965: 71). ${ }^{6}$ It also noted that some English-Canadians outside of Quebec "were very modest and frank 
in admitting that they knew hardly anything about recent developments in the Province of Quebec. They blamed their ignorance on the failure of the mass media to do an adequate job of keeping them informed" (Canada 1965: 72).

In an unpublished study submitted to the B\&B Commission, Neil Compton went still further in linking the media to what English Canada saw as the crisis of Quebec nationalism:

The fact that so many English Canadians are still pathetically asking "What does Quebec really want?" is a sign not merely of ignorance but of the extreme difficulty of communication across this particular cultural boundary. [...] In truth, one can learn "what Quebec wants" only by entering imaginatively into the life of her people. The salvation of Canada may depend on the ability of a substantial minority of the English population to do just that. [...] Here is an apparently natural task for the new media of communications. (1965: 12-13)

Later, he lamented that "we are astonishingly short of 'cultural middlemen' capable of explaining and interpreting French Canada to the rest of the country (and viceversa, for that matter)" (Compton 1965: 27).

The same year the $\mathrm{B} \& \mathrm{~B}$ Commission released its preliminary report, there was a proposal at the Corporation to "create a national news service to be situated in Ottawa," but as a CRTC report said more than a decade later, "though at first greeted with enthusiasm, [it] posed so many problems that it was abandoned" (CRTC 1977: 60). The CRTC's report does not say what techniques the service would have used (subtitles, dubbing, simultaneous interpreting, etc.), nor does it say whether the proposal was prompted by the B\&B Commission. But another unpublished study submitted to the $\mathrm{B} \& \mathrm{~B}$ Commission gives some sense of why it failed. One principal reason was the asymmetry in language skills between Francophone and Anglophone journalists, who bore the burden of translation differently: a greater percentage of Francophones were bilingual than Anglophones, and they were also more likely to be familiar with English Canadian culture than vice versa (Chartrand McKenzie 1967).

The threat of Quebec separatism led to another commission in 1977, just after Parti Québécois leader René Lévesque became the premier of Quebec on the promise of holding a referendum on sovereignty-association. That year, in response to the idea (advanced by Prime Minister Pierre Trudeau) that journalists at Radio-Canada were biased in favour of the separatist movement, the CRTC convened the Committee of Inquiry into the National Broadcasting Service and gave it the task of "inquir[ing] into the manner in which the $\mathrm{CBC}$ is fulfilling its mandate [to contribute to national unity], particularly with respect to public affairs, news, and information programming" (CRTC 1977: 1). The committee described the situation between the Englishand French-language networks as "cultural apartheid":

Each network's lack of interest in the other part of Canada is reinforced by differences in outlook, spirit, and working methods between French- and English-speaking journalists. It is reinforced, even more, by a structural organization in the $\mathrm{CBC}$ that a well-known and respected $\mathrm{CBC}$ personality has trenchantly described as a "working model of how the country will fail." (CRTC 1977: 55, 58)

The networks cooperated when producing stories about one-off events such as "elections, conventions, political debates, special events like [the 1967 International and Universal Exposition in Montreal], royal visits, investitures of the Governor- 
General, [and] openings of Parliament," but otherwise, "[i]n news and current affairs, there has been a failure to pool talent, equipment, and effort" (CRTC 1977: 60). Instead of recommending bilingual or translated news, however, the committee recommended that the English- and French-language services pay more attention to each other and work to cover a less divergent set of stories in a less divergent way, something they managed to do in the short term, but not the long term (Siegel 1979; de Bonville and Vermette 1994).

These "near misses," especially from the 1960s and 1970s, raise two questions about competing interests and the history of news translation in Canadian broadcasting. The first relates to translation itself. Why didn't the Canadian Broadcasting Corporation create a program that used translation in some form to address Anglophones and Francophones at the same time? In part, Ottawa's priorities shifted over the course of the B\&B Commission's inquiry. In its consultations with Canadians, the commission encountered a lot of resistance from people of nonEnglish and non-French origins who objected to the idea of biculturalism. As a result, the fourth volume of the commission's report, called The Cultural Contribution of the Other Ethnic Groups, raised concerns that drew the initial premises of two languages and two cultures into question. Among them were concerns about broadcasting. The commission recommended that the CRTC and the Canadian Broadcasting Corporation lift restrictions that prevented the use of languages other than English or French in private and public broadcasting and that the CRTC

undertake studies in the field of broadcasting in other languages to determine the best means by which radio and television can contribute to the maintenance of languages and cultures and that the CBC participate in these studies. (Canada 1969: 229)

Ottawa, in turn, used the B\&B Commission's report to justify the implementation of Canada's first multicultural policy in 1971. In its response to the B\&B Commission's recommendations, the federal government said it would instruct the CRTC and the Canadian Broadcasting Corporation to undertake studies to assess their feasibility (Canada 1971). But making multiculturalism official policy served another purpose: it undercut arguments in support of Quebec nationalism by breaking the link between language and culture. Quebec Premier Robert Bourassa (1975) was also concerned that it weakened the province's ability to look after its own affairs in ways that protected its largely Francophone population.

In other words, ideas about news translation were merely incidental, and they did not rise to the same level of importance as the politics of Quebec nationalism. At the heart of the B\&B Commission's report was a paradox: at first, the commission's mandate was to find ways to improve relations between Canada's two major linguistic and cultural groups, but in the end, its report served to justify a policy that appeared to weaken Quebec's position in the Canadian confederation. Here we arrive at the second question about competing interests, which relates to the creation (or not) of archives. One plausible explanation for the lack of documents about attempts to provide translated news is that they did not seem as important as documents about more consequential matters, such as multicultural policy. As a result, records remain only in para-archival documents such as those examined here: royal commission reports, unpublished submissions to the B\&B Commission, and CRTC reports. 


\section{Translated news on Newsworld and the Réseau de l'information ${ }^{7}$}

The records of the best documented attempt to bring translated news to Canadian television also exist outside any official Corporation archive, but because they are more recent, they benefit from the trend of digitization. The CRTC has made most of its decisions available electronically, and the Fédération professionnelle des journalistes du Québec, which opposed some of the efforts described below, posts many documents to its website.

With better access to such documents, what Trouillot calls the "moment of fact retrieval" becomes easier, and the narrative becomes clearer. In the previous section, I proposed explanations for the lack of translated news in the 1960s and 1970s, but because documents were not preserved, it would be impossible to prove or disprove them. In this section, the situation is different. Here I examine attempts by the Canadian Broadcasting Corporation, first, to air subtitled versions of Radio-Canada's Le Téléjournal on Newsworld, its English all-news cable network, and second, to provide subtitled news to what would become the Réseau de l'information (RDI), its French all-news cable network. These efforts, too, did not result in the production of translated news for reasons related to the asymmetry of usage and prestige of English and French in Canada and the fact that the priorities of Corporation executives lay elsewhere.

In Canada, the late 1980s and early 1990s were marked by efforts to find a way to recognize Quebec's place in Confederation so it would formally accept the patriation of Canada's constitution from London, which took place in 1982 over Quebec's objections. Canada's federal and provincial leaders arrived at two accords, one negotiated at Meech Lake, Quebec, in 1987 and the other in Charlottetown, Prince Edward Island, in 1992, that would have recognized Quebec as a "distinct society" and granted it varying degrees of autonomy in areas such as immigration and taxation. Neither accord passed: the Meech Lake Accord failed to gain approval in Manitoba's and Newfoundland's legislatures, while the Charlottetown Accord failed in a popular referendum.

After Meech Lake's failure, Canada's two linguistic groups felt increasingly alienated from each other, a situation that led Keith Spicer, chair of the CRTC, to opine in a speech he gave in Toronto in 1990:

$\mathrm{CBC}$, both radio and TV, does a lot for understanding among Canadians. But let me give you a small example of the remaining potential. During the Sault-Ste-Marie language nonsense [when the city council passed a controversial resolution declaring English the official language of the municipal government], we saw and heard mainly from the extremists - and French Canada, on its news, heard almost exclusively the English-Canadian extremists. A dialogue of the deaf, and of the blind. I wonder what might have been achieved by subtitling the national TV news of English and French Canada - the French news with English subtitles outside Quebec, and the English news with French subtitles within Quebec.

Naive? Impractical? The other day in Paris, I watched the TV news in my room from Germany, Italy and Spain - all with French subtitles. And the Europeans aren't building a country, just a closer-knit continent. (Spicer 1990)

In fact, the idea of subtitled news was in the air. In different contexts, such as the House of Commons Standing Committee on Communications and Culture, politicians were making similar claims about what it could do (see Conway 2011: 39). It 
was also part of the Corporation's application in 1987 for a license for what would become Newsworld. In its application, the Corporation argued that most of the news available to Anglophone Canadians was produced outside Canada and was therefore ill-suited to a Canadian perspective. It argued further that Canadians wanted Canadian news. It also promised to air subtitled versions of Le Téléjournal, the French-language flagship evening news program, from 11:00 pm to midnight to encourage mutual understanding between English Canada and Quebec (CRTC 1987). The CRTC approved the application, but because of problems related to the fees cable subscribers would pay, Newsworld did not launch until 1989. At that time, it pushed Le Téléjournal back to 1:00-2:00 am, where it did not attract many viewers. After a few months, Newsworld replaced Le Téléjournal with reruns of various international reports (see Conway 2011: 48).

More interesting were the attempts by the Corporation to provide subtitled versions of English-language programs for viewers in Quebec. When the CRTC approved Newsworld's license, it said it was concerned that "a service of the type proposed in this application might be equally urgent for French Canadians and that the Corporation's mandate under section 3 of the Broadcasting Act requires the provision of services in both languages" (CRTC 1987). The Corporation argued that the news-gathering infrastructure of its English-language service was better developed than that of its French-language service, especially in regions outside of Quebec. The CRTC accepted that explanation provisionally but required the Corporation

to submit, within one year of the date of this decision, the findings of a feasibility study for implementing a French-language news and information of such a service could only be undertaken on a gradual basis or in association with other public or private partners. (CRTC 1987)

In 1989, the Corporation submitted a proposal for a "French Newsworld," but the network it proposed would carry very little original programming. The CRTC rejected the proposal, stating,

the Commission does not share the [Corporation's] contention, stated at the hearing, that the service as proposed could be $[\ldots]$ "the French-language counterpart of the English-language service" authorized by the Commission in 1987. Nor does the Commission accept the [Corporation's] claim that it would be "a French-language equivalent of Newsworld." The Commission notes by way of comparison that approximately half of the Newsworld service's 168 -hour weekly schedule consists of original programs. (CRTC 1989)

The CRTC maintained pressure on the Corporation but put it in a bind by enacting a moratorium on new services until 1994. As a stopgap measure, when the Corporation applied to renew its license for Newsworld in 1991, it included a proposal to provide four hours of subtitled English-language news to cable providers in Quebec.

The Fédération professionnelle des journalistes du Québec objected vociferously to this plan. By their account,

[c]ette proposition [...] ferait passer l'information destinée aux francophones sous la coupe d'une société anglophone, dirigée par des anglophones et concevant leur information en fonction du public anglophone. Aux francophones on accorderait le privilège de goûter à cette manne... en version traduite. (Saulnier 1991) 
Moreover, it saw the same problems with Newsworld as the Corporation had described with respect to U.S. news sources in its original Newsworld license application:

La traduction en français de l'information produite par Newsworld est un non-sens journalistique. [...] Si l'information de CNN n'est pas bien adaptée au public du Canada anglais, comment peut-on penser que l'information de Newsworld serait bien adaptée au public francophone? (Saulnier 1991)

The Fédération's objections make clear the ways that the failure - or in this case, refusal - to produce translated news was a product of cultural and political factors in addition to factors related to language skills. Its biggest concern was that the provision of subtitled news might perpetuate the inequality between the Corporation's English and French networks (the French network's infrastructure has long been less developed) by "short-circuiting" the application process for a French equivalent to Newsworld (Saulnier 1991).

Beyond the language politics of broadcasting, a second factor contributed to the failure to produce translated news. During the late 1980s and early 1990s, Parliament cut funding for the Canadian Broadcasting Corporation. The most dramatic of the cuts came in December 1990, when the Corporation lost \$108 million from its budget. Those cuts prompted Corporation executives to look for ways to distinguish the $\mathrm{CBC}$ and Radio-Canada from their competitors. As cable grew in popularity, its programming strategies began to shape how over-the-air broadcasters (such as the CBC and Radio-Canada) thought about attracting viewers. Specialty "narrowcast" cable stations tried to establish niche audiences based on content (such as news) or demographics (such as networks targeting women or minorities). The Corporation responded by carving out a niche of its own, and its networks began to adopt an "obsessively local" strategy (Lumb 1991). By 1993, that strategy had evolved into one according to which the CBC and Radio-Canada would be narrowcasters whose niche was Canadian content (Veilleux 1993). This local, Canadian content strategy had a second benefit: it allowed the Corporation to save money by consolidating local production, especially in news, in regional centres. In 1994, when the CRTC issued a license for the Réseau de l'information, it noted: "the Corporation intends to give emphasis to the production role of its stations and affiliates with a view to expanding their participation and providing a better reflection of all regions of the country" (CRTC 1994). This regional emphasis obviated the need for translation: RDI would use its own Francophone journalists at bureaus across the country. It had little need for reports from the Corporation's English-language networks.

The availability here of archives other than the Corporation's, the similarities between Newsworld and RDI, and the examples in the previous section suggest that my explanation for the lack of translated news in the 1960s and 1970s is not too far off the mark. In both cases, the asymmetry between English and French in Canada influenced journalists' approach to their profession: because there were more Anglophones than Francophones in Canada, more Francophones spoke English than the other way around. Although there were of course bilingual Anglophones, Francophones in general bore a disproportionate burden when it came to any coproduction between linguistic groups. Thus they were reluctant to participate in a plan that, as they saw it, put them and their networks at a further disadvantage. At the 
same time, policy-makers' and executives' priorities worked against the production of translated news. In the 1960s and 1970s, federal policy-makers were concerned with countering rising nationalist sentiment in Quebec, which meant proposing broadcasting policies to respond to the concerns of Canada's ethnic minorities. In the 1990s, network executives were concerned with finding a broadcasting model to help them compensate for cuts in funding. In neither case, however, would translated news have served a useful purpose.

\section{Conclusion: fragile evidence and plausibility}

Earlier I argued that news translation (in particular the history of news translation) presents no ready-made object of study and that, instead, scholars actively create their objects through the questions they ask. How does my examination of the Canadian Broadcasting Corporation illustrate that assertion? The questions I asked were these: at what points have people proposed that the Corporation produce translated news? What problem did translated news appear to solve? Why were such proposals not acted upon? Ideally, the object of study would have been official documents describing these proposals, but since they were not preserved, the object became the "silence" itself. That absence raises a different series of questions: in the cases before the 1990s, why weren't these documents preserved? Or more to the point, what circumstances made them appear so trivial that their creators did not think to preserve them? Conversely, in the case of Newsworld and the Réseau de l'information, who thought they were important enough to preserve, and why? The Fédération des journalistes du Québec had a specific agenda - to uphold professional standards - that differed from the aspirational goals of people such as Keith Spicer, who wanted to encourage intercultural communication. My account of that episode would likely have looked different if the Corporation had saved its memoranda about translated news on its cable networks - the FPJQ emphasized conflict, while the Corporation might have emphasized cooperation and mutual understanding, if Spicer's comments are any indication.

These questions register the shift in emphasis from translation to translator that has characterized recent translation historiography (Pym 1998). There are no translations to examine. Instead, the questions about preservation turn our attention back to the policy-makers and journalists who occupied an intermediary position between linguistic communities. It is significant that the proposals I describe came at moments of crisis: the crises provided problems that translated news appeared potentially to solve. Supporters and opponents made appeals to two things - culture and funding - when arguing for or against the production of translated news. ${ }^{8}$ In the 1960s, culture and the competing nationalist sentiments it engendered in English Canada and Quebec predominated. Supporters of translated news thought that English-Canadians did not understand Quebec and that seeing the same news would help. But by the 1990s, the question of funding had grown more important, especially in the wake of the cuts imposed by Brian Mulroney's government in 1990. Questions of cultural identity remained important (indeed, they were central to the Meech Lake and Charlottetown accords), but they cut both ways. Supporters of translated news made arguments similar to those of their predecessors in the 1960s (seeing the same news would encourage mutual understanding), but opponents countered with cul- 
tural arguments of their own (the provision of news translated from English to French would privilege English Canadians' concerns over those of Francophone Quebeckers). Where funding was concerned, however, opponents had the stronger argument: translated news was not likely to attract enough viewers to be profitable, and given the falling rates of parliamentary support, providing it was untenable (see Conway 2011: 51-54). By the 2010s, funding was a more important factor than culture. Although culture remained relevant (it was the basis of the proposal published in the Toronto Star), questions of national unity did not appear as urgent because the Quebec separatist movement did not have the support it had had in the 1990s or the 1960s. Jean Charest's Liberal government was in its final days, to be replaced by a minority Parti Québécois government by year's end. Thus commenters on the Toronto Star's website were far more likely to react to issues of practicality and funding. One commenter, quoting the author's biographical note, wrote, "David Eaves is a public policy expert and consultant.' ... and clearly not a broadcaster. Who would watch a mess of a news show like that?" Another added, "How does a loon like this get a soapbox?" Translated or bilingual news would be a new expense for the Corporation, something that would be a political impossibility in an era of budget cuts.

In this respect, the field of history, to the degree it is responsible for the shift in emphasis from translations to translators, should cause Translation Studies scholars to reflect on the nature of the evidence at their disposal. If anything, this shift points to places where evidence is fragile: the claims I have made here, in the final analysis, are non-falsifiable. Instead, what makes an argument convincing is its plausibility: rather than test hypotheses, we evaluate competing narratives' relative strengths based on the answers they provide to questions about different actors' actions and motivations. In the case of the Canadian Broadcasting Corporation, the silence in the archive reveals a hidden history of translation, and examining the failure of efforts to provide translated news provides insight into the broader relationships of power between Canada's principal linguistic and cultural groups.

\section{NOTES}

1. For the sake of consistency, I will use "Canadian Broadcasting Corporation" or simply "the Corporation" to refer to Canada's public broadcaster. I will use "CBC" to refer to its Englishlanguage broadcast network and "Radio-Canada" to refer to its French-language broadcast network.

2. The most extensive historical treatment of news translation appears in Translation in Global News, where Esperança Bielsa and Susan Bassnett (2009) introduce their analysis of translation in global news agencies by first discussing the intertwined histories of technology (from the telegraph to the internet) and the rise of the news agency as a provider of news. Still, their history concerns the agencies themselves, not agencies' approach to translation. Although their discussion of translation is rich, it concerns only present-day practices.

3. Table 1 reflects the current state of the literature on news translation, where analysis of print or print-derived media such as internet predominates. Television has received limited attention, but, to my knowledge, radio has received none at all. See van Doorslaer (2010b).

4. The 1968 Broadcasting Act, for instance, required the Corporation's networks to "contribute to the development of national unity and provide for a continuing expression of Canadian identity" (\$2.g.iv), while the 1991 Broadcasting Act required them to "contribute to shared national consciousness and identity” (\$3.1.m.iv). The 1991 Act contained similar mandates to represent Canada’s regions and its multicultural character.

5. His article was called "Can the CBC Bridge the Two Solitudes?" and was originally posted on March 20, 2012 at thenetwork.thestar.com/expert-opinion/can-the-cbc-bridge-the-two-solitudes/20120320/. It has since been deleted. 
6. Although the first volume of the B\&B Commission's final report describes research undertaken on the mass media (Canada 1967: 194-195), it does no more than preview what the commissioners intended to write. For reasons that are nowhere explained, the rest of the final report addresses the media in a substantive way only in the volume on "the other ethnic groups" (Canada 1969). For research on English and French media, historians are left with a series of unpublished studies submitted to the commission (e.g., Chartrand McKenzie 1967 and Compton 1965; for a complete list, see Canada 1967: 207).

7. For a more detailed account of the episode described here, see Conway (2011: 37-59).

8. It is worth noting that funding was contingent on lawmakers' sense of whether the Corporation was performing its job, which included contributing to Canadian culture by encouraging communication across linguistic and cultural lines.

\section{REFERENCES}

Bielsa, Esperança and Bassnett, Susan (2009): Translation in Global News. New York: Routledge. Bourassa, Robert (1975): Objections to multiculturalism. In: Howard PALmer, ed. Immigration and the Rise of Multiculturalism. Toronto: Copp Clark, 151-152.

Canada, Royal Commission on Bilingualism and Biculturalism (1965): Preliminary report. Ottawa: Queen's Printer.

Canada, Royal Commission on Bilingualism and Biculturalism (1967): Report, Book I: The Official Languages. Ottawa: Queen's Printer.

Canada, Royal Commission on Bilingualism and Biculturalism (1969): Report, Book IV: The Cultural Contribution of the Other Ethnic Groups. Ottawa: Queen's Printer.

Canada, House of Commons (1971): Federal Government's Response to Book IV of the Report of the Royal Commission on Bilingualism and Biculturalism. Debates. 8 October: 8580-8585.

CBC (1988): Journalistic Policy. Ottawa: CBC.

Chartrand McKenzie, Francine (1967): Les journalistes anglo- et franco-canadiens: leurs opinions et leurs comportements vis-à-vis de la coexistence des deux cultures au pays. Report prepared for the Royal Commission on Bilingualism and Biculturalism (div. VII, no. 15a).

Сомpton, Neil (1965): Biculturalism and the English Language Media. Study prepared for the Royal Commission on Bilingualism and Biculturalism (div. VII, no. 3).

Conway, Kyle (2011): Everyone Says No: Public Service Broadcasting and the Failure of Translation. Montreal: McGill-Queen's University Press.

CRTC, Committee of Inquiry into the National Broadcasting Service (1977): Report. Ottawa: CRTC.

CRTC (1987): Decision CRTC 87-904. Visited 22 June 2013, <www.crtc.gc.ca/eng/archive/1987/DB87904.htm>.

CRTC (1989): Decision CRTC 89-599. Visited 22 June 2013, <www.crtc.gc.ca/eng/archive/1989/DB89-599. htm>.

CRTC (1994): Decision CRTC 94-285. Visited 22 June 2013, <www.crtc.gc.ca/eng/archive/1994/DB94285.htm>.

de Bonville, Jean and Vermette, Jacques (1994): Télévision et unité nationale: la couverture de l'actualité canadienne à Radio-Canada. Canadian Journal of Political Science. 27(4):699-716.

D’hulst, Lieven (2010): Translation history. In: Yves Gambier and Luc van Doorslaer, eds. Handbook of Translation Studies. Vol. 1. Visited 11 June 2013, <benjamins.com/online/hts/>.

D’HULST, Lieven (2012): (Re)locating translation history: From assumed translation to assumed transfer. Translation Studies. 5(2):139-155.

Everton, Neil, ed. (1999): CBC Television Style Guide. Toronto: CBC Training and Development.

FuJII, Akio (1988): News translation in Japan. Meta. 33(1):32-37.

GolDSCHEIDER, Eric (2004): Found in translation. Boston Globe Magazine. 24 October. Visited 29 October 2004, <www.boston.com/news/globe/magazine/articles/2004/10/24/found_in_translation>.

KANG, Ji-Hae (2012): Translating mad cow disease: A case study of subtitling for a television news magazine. Meta. 57(2):439-463.

Knight, Tim (2003): The Television Storyteller: A Guide for TV Journalists. Toronto: CBC Learning and Development.

Lumb, Lionel (1991): Provincializing the CBC. Content. November-December:7-10.

McLaughlin, Mairi (2011): Syntactic Borrowing in Contemporary French: A Linguistic Analysis of News Translation. Oxford: Legenda. 
O'Sullivan, Carol (2012): Introduction: Rethinking methods in translation history. Translation Studies. 5(2):131-138.

PyM, Anthony (1998): Method in Translation History. Manchester: St. Jerome.

SAUlnier, Alain (1991): Renouvellement du permis de CBC-Newsworld: Les francophones méritent mieux que des informations traduites! Visited 12 June 2013, <www.le30.org/index.php?id=68>.

Siegel, Arthur (1979): French and English broadcasting in Canada - A political evaluation. Canadian Journal of Communication. 5(3):1-17.

SPICER, Keith (1990). Broadcasting in the nineties: New balances, new perspectives. The Empire Club of Canada Addresses (Toronto, Canada). 24 May. Visited 8 July 2014, <http://speeches.empireclub. $\operatorname{org} / 61362 /$ data?n=34)>.

Stetting, Karen (1989): Transediting - A new term for coping with the grey area between editing and translating. In: G. D. CAIE, ed., Proceedings from the Fourth Nordic Conference for English Studies. Copenhagen: University of Copenhagen Department of English, 371-382.

St. James, Halina (2002): Performing the CBC news. Toronto: CBC Learning and Development.

Trouillot, Michel-Rolph (1995): Silencing the Past: Power and the Production of History. Boston: Beacon Press.

Tsai, Claire (2005): Inside the television newsroom: An insider's view of international news translation in Taiwan. Language and Intercultural Communication. 5(2):145-153.

VAldeón, Roberto A. (2009): Discursive constructions of terrorism in Spain: Anglophone and Spanish media representations of Eta. International Journal of Applied Linguistics. 19(1):66-83.

van Doorslaer, Luc (2010a): The double extension of translation in the journalistic field. Across Languages and Cultures. 11(2):175-188.

van Doorslaer, Luc (2010b): Journalism and translation. In: Yves Gambier and Luc van Doorslaer, eds. Handbook of Translation Studies. Vol. 1. Visited 11 June 2013, <benjamins.com/online/hts/>.

VeIlleux, Gérard (1993): Repositioning/Le repositionnement. Toronto: CBC Research Centre.

Werner, Michael and Zimmerman, Bénédicte (2003): Penser l'histoire croisée: entre empirie et réflexivité. Annales HSS. 58(1):7-36. 